\title{
Askorbik Asit ile Desteklenmiş Yumurta Tavuğu Rasyonlarının Bazı Verim ve Kan Parametrelerine Etkisi
}

\author{
Mevlüt GÜNAL ${ }^{1}$ Muzaffer ÇÖRDÜK² $\quad$ Giti HESHMET ${ }^{2}$ Şahibe ÇALIŞKANER ${ }^{2}$
}

Geliş Tarihi: 16.09.1998

\begin{abstract}
Özet: Araştırmada 26 haftalık yaşta 80 adet yumurta tavuğu $17-31^{\circ} \mathrm{C}$ sıcakliklarda 4 tekerrürlü 4 deneme grubuna dağıtılarak 12 hafta süreyle beslenmişlerdir. Mısır-soya esasłı izokalorik ve izonitrojenik hazırlanan rasyonlara $\% 0.00, \%$ $0.15, \% 0.30, \% 0.45$ düzeylerinde askorbik asit ilave edilerek, bazı performans, yumurta ve kan parametrelerine etkisi incelenmiştir.

Araştırmada; yem değerlendirme sayısı, deneme başı ve sonu canlı ağırlıklar, yumurta ağırlığı, kabuk ağırlığı, kabuk oranı, kabuk küt kalınlığı ile ortalama kabuk kalınlığı, yumurta akı uzunluğu ve yüksekliği, yumurta sarısı yüksekliğ ve genişliği, yumurta sarısı indeksi, kırık-çatlak oranı, ölüm oranı ile serum askorbik asit ve kalsiyum değerleri arasında ónemli derecede farklilık saptanmamı $(P>0.05)$, kontrol grubu diğer gruplardan yumurta verimi, yem tüketimi, kabuk mukavemeti ve yumurtanın sivri ucuna ait kabuk kalınlığı açısından önemli olmayan derecede düşük $(P>0.05)$, yumurta akının genişliği açısından ise kontrol grubu, \% 0.45 askorbik asit içeren gruptan önemli derecede daha yüksek değerler göstermiştir $(P<0.05)$.

Sonuç olarak; $17-31^{\circ} \mathrm{C}$ sıcaklıklarda yumurta tavuğu rasyonlarına \% $0.45^{\prime}$ e kadar ilave edilen askorbik asitin, yumurta verimi, yem tüketimi, kabuk mukavemeti, yumurtanın sivri tarafındaki kabuk kalınlığı ile kan parametreleri açısından olumiu sonuçlar verdiği söylenemez.
\end{abstract}

Anahtar Kelimeler: Yumurta tavuğu rasyonlan, askorbik asit, performans, yumurta ve kan parametreleri

\section{The Effects of Ascorbic Acid Supplementation of Layer Rations Some Production and Blood Parameters}

\begin{abstract}
In this research, were fed 80 layer, during months $17-31^{\circ} \mathrm{C}$, were fed in 4 experimental groups with 4 replicates for 12 weeks. The effects on performance, egg and blood parameters of supplementation at the leveis of $0.00 \%, 0.15 \%, 0.30 \%, 0.45 \%$ ascorbic acid to corn- soyabean meal based rations were investigated. Diets were formulated isocaloric and isonitrogenic.

In the research for the groups feed efficiency, initial and final weight, egg weight, shell ratio, shell centre and stubby thickness, average shell thickness, albumen length and height, yolk height and width, broken or crack egg, mortality, serum ascorbic acid and calcium were not found statically different $(P>0.05)$. Hovewer, egg production, feed consumption, shell resistance, shell sharp thickness of control group were lower than other groups. Differences were not significant $(P>0.05)$. Albumen width of control group was found statically higher than 4 th group includig $0.45 \%$ ascorbic acid $(P<0.05)$.

As a results of experiment, supplementation of ascorbic acid can not be recommended up to $0.45 \%$ in layer rations for blood parameters, egg production, feed consumption, shell resistance and shell sharp thickness, in $17-31^{\circ} \mathrm{C}$.
\end{abstract}

Key Words : Layer rations, ascorbic acid, performance, egg and blood parameters

\section{Giriş}

Yetişkin kanatıların askorbik asidi yeterince sentezledikleri kabul edilerek, genellikle rasyonla verilmesine gerek kalmayacağı bildirilmektedir (Anonim 1984). Ancak modern kanath yetiştiriciliğinde hayvanlar genellikle fizyolojik dengelerini bozan çevre sıcaklığı, nem, yüksek verimlilik oranı, parazitik enfeksiyon, yetersiz besleme, gaga kesimi, fiziksel darbeler gibi birçok istenmeyen stres faktörlerine maruz kalmaktadirlar. Bu stres faktörlerinden bazıların ortamdan uzaklaştırmak mümkün ise de, bazıları üretimin bir parçası olarak yer almaktadırlar. Kanatı hayvanlar iklimsel çevre koşullarına daha duyarlıdırlar ve metabolizmalarını çevre sıcaklığına göre düzenleme eğilimindedirler. Bu nedenle bu hayvanlarda kalitsal yapidan optimum oranda yararlanmada ve yemden yararlanmanın ekonomik sınırlar içerisinde tutulmasında iklimsel çevre en önemli etkenlerdendir.

Bununla birlikte Dünyanın birçok yöresinde özellikle yumurta tavukları sıcaklık stresi ile karşı karşıyadırlar.

\footnotetext{
'Süleyman Demirel Üniv. Ziraat Fak., Zootekni Bölürnü, Isparta.

${ }^{2}$ Ankara Üniv. Ziraat Fak., Zootekni Bölümü, Ankara.
} 
Bu hayvanlarda yüksek çevre sıcaklığı yumurta verimini, yumurta ağırlığını ve kabuk kalınlığını olumsuz yönde etkilemektedir (Marsden ve ark. 1987). Kümeslerde iklimsel çevre denetiminde yönetsel tedbirlerden birisi besleme sisteminde yapılabilecek değişikliklerdir. Besleme çalışmalarında genel olarak sıcaklık stresi altındaki hayvanların bozulan fizyolojik dengelerinin yeniden kurulmasi veya sicaklık stresi altında verimi etkileyen besin maddesi yada besin maddelerinin tesbit edilerek o yönde takviyelerin yapılması amaçlanmaktadır (Kutlu 1996). Bu yöntemlerden birisi; stres faktörierin söz konusu olduğu ortamlarda yetiştirilen kanatıların sentezledikleri askorbik asit miktarının gereksinmeyi karşılayacak düzeyde olmadığı varsayılarak, bu hayvanların yem veya sularına askorbik asit ilavesinin yapılmasıdır.

Organizmada bir çok fonksiyonu bulunan askorbik asit yumurta tavukları için oldukça önemli sayılabilecek bazı fizyolojik olaylarda da görev alır. Bu görevlerden en önemlileri; mineralizasyonun uygun şekilde gerçekleşmesinde gerekli olan kollagen oluşumunda, Vitamin $\mathrm{D}_{3}$ 'ün aktif metabolitlerine dönüşümünde ve kalsiyumun proteinlere bağlanarak absorbsiyonunun arttırılmasında rol oynamasıdır.

Sicaklık, yetersiz besleme, tüy dökümü, gaga kesimi, hastalık, aşılama, yüksek verimlilik oranı, mineral fazlalığı, toksikasyon gibi çeşitli stres koşullarında askorbik asidin 22 ppm'den 5000 ppm'e kadar yeme yada suya ilavesinde performans, yumurta yada kan parametreleri üzerinde çeşitli araştırıcılar değişik sonuçlar almışlardır. Rasyona askorbik asit ilavesinin Hunt ve Aitken (1962), Sullivan ve Kingan (1962), Perek ve Kendler (1962), Kolb (1990), Nir (1990), Haazele ve ark. (1991) yumurta verimini, Thornton ve Moreng (1958), Sullivan ve Kingan (1962) kabuk ağırlığını, Perek ve Kendler (1962), Njoku ve ark. (1990). Cheng ve ark. (1990) yumurta ağırlığı ve iç kalitesini, Kolb (1990), Cheng ve ark. (1990) kabuk ağırığını, Orban ve ark. (1993), Haazele ve ark. (1991) plazma kalsiyum seviyesini, Herrick ve Nockels (1969), Perek ve Kendler (1962) plazma askorbik asit seviyesini yükselttiğini, Njoku ve ark. (1990) yem değerlendirme sayısını iyileştirdiğini bildirmektedirler. Buna karşin Thornton ve Moreng (1958), Benabdeljelil ve ark. (1990), Njoku ve ark. (1990) yumurta verimini, Herrick ve Nockels (1969), Erdinç (1977), Benabdeljelil ve ark. (1990) kabuk ağırlığını, Herrick ve Nockels (1969), Keckick ve Sykes (1974) yumurta ağırlığ ve yumurta içi kalitesini, Perek ve Kendler (1962), Nir (1990), Njoku ve ark. (1990) kırık-çatlak yumurta oranını, Perek ve Kendler (1962), Cheng ve ark. (1990) ölüm oranını, Benabdeljelil ve ark. (1990) canlı ağırık artışın, Andrews ve ark. (1987) yem değerlendirme sayısını, Rowland ve ark. (1973) plazma kalsiyum seviyesini etkilemediğini bildirmektedirler.

Bu araștırmada yumurta tavuğu rasyonlarına ilave edilen $\% \quad 0.00, \% \quad 0.15, \% \quad 0.30, \% \quad 0.45$ düzeylerinde askorbik asitin bazı performans, yumurta ve kan parametrelerine etkisi incelenmiştir.

\section{Materyal ve Yöntem}

Araştırmanın hayvan materyalini 80 adet 26 haftalık yaşta Hy-Line yumurta tavuğu oluşturmuştur. Araştırmada kullanılan askorbik asit etil selülozla kaplanmış (coated) formda \% 97.5 aktif madde içeren, biyolojik yararlılığı yüksek, oksidasyona kısmen dayanıklı askorbik asit türevidir. Araştırmada kullanılan askorbik asit Roche Müstahzarları A.Ș.'den, diğer yem maddeleri Ankara Üniversitesi Ziraat Fakültesi Kenan Evren Araştırma Uygulama Çiftliğinden temin edilmiștir

Deneme, 4 grupta, her grupta 4 tekerrür ve her tekerrürde 5 tavuk bulunacak şekilde ferdi kafeslere Tesadüf Parselleri Deneme Desenine (Düzgüneş ve ark. 1983) göre dağıtılmış ve Ankara Üniversitesi Ziraat Fakültesi Zootekni Bölümü yumurta tavukçuluğu kümesinde yürütülmüştür. Denemede kullanılan yem maddelerinde ham besin maddesi analizleri (Akyildız 1984) yapıldiktan sonra, gereksinim düzeyleri (Anonim 1984) dikkate alınarak deneme rasyonları oluşturulmuştur. Yem maddelerinin diğer besin maddeleri literatürden alınmıștır (Akyıldız 1979).

Denemede misir-soya ağırliklı rasyonlara $\% \quad 0, \%$ $0.15, \% \quad 0.30, \% \quad 0.45$ düzeylerinde askorbik asit ilave edilmiştir. Buna karşın rasyonlardaki buğday kepeği düzeyi askorbik asit ilavesi oranında azaltılmıştır. Bu esasa göre hazırlanan deneme rasyonlarının yapısı Çizelge 1 'de verilmiştir.

Deneme gruplarındaki hayvanlar ferdi bölmelerde barındırılmış, yem ve su serbest verilmiştir. Gruplardaki tavukların yem tüketimleri haftalık tartımlarla, ölümler gününde kaydedilerek, alt grupların yem tüketim ve yumurta verimlerinin hesaplanmasında bu durum dikkate alınmıştır. Yumurta verimleri ve kümes sıcaklıkları günlük kaydedilmiştir. Deneme kümesinde tesbit edilen maksimum ve minimum ortalama sıcaklıklar haftalara göre Çizelge 2'de verilmiş̧ir.

Deneme 28.06.1995 tarihinde başlatılmış ve 12 hafta sonra 20.09.1995 tarihinde bitirilmiştir.

Yem maddelerinde ve deneme gruplarina ait karmalarda ham besin maddesi analizleri Weende analiz yöntemine göre (Akyıldız 1984) yapılmıştır. Deneme gruplarında her 14 günde bir, her grubu temsilen 20 yumurtada yumurta ağırlığı, kabuk ağırlığı, kabuk kalınlığı (zarı çıkarılmış), kırılma mukavemeti ile yumurta akı genişliği, uzunluk ve yüksekliği, yumurta sarısının genişlik ve yükseklik değerleri tesbit edilmiştir. Kalınlık ve yükseklik değerleri üç ayaklı mikrometre ile, genişlik ve uzunluk değerleri sürgülü kumpas ile, kırılma mukavemeti $\left(\mathrm{kg} / \mathrm{cm}^{2}\right)$ mukavemet ölçüm aletiyle yapılmıştır. Denemede gruplara ait kabuk kalınlığı ile ak ve sarı indeksleri, ilgili hesaplamalar yapilarak bulunmuştur. Ak indeksi= (ak yüksekliği / (ak uzunluğu+ak genişliği/2)) $\times 100$ formülüyle, Sarı indeksi= (sarı yüksekliği I sar genişliği)x100 formülüyle hesaplanmıştır. Ortalama kabuk kalınlığı ise yumurtanın küt kısmındaki kabuk, orta ve sivri uçtaki kalınlıklarının ortalaması alınarak bulunmuştur. 
Çizelge 1. Deneme rasyonlarının yapıları

\begin{tabular}{|c|c|c|c|c|}
\hline \multicolumn{5}{|c|}{$D e n e m e$} \\
\hline Yem maddeleri & $T$ & II & III & IV \\
\hline Buğday & 10.00 & 10.00 & 10.00 & 10.00 \\
\hline Buğday kepeği & 6.90 & 6.75 & 6.60 & 6.45 \\
\hline Misır & 48.00 & 48.00 & 48.00 & 48.00 \\
\hline Soya küspesi & 18.00 & 18.00 & 18.00 & 18.00 \\
\hline Bailk unu & 4.00 & 4.00 & 4.00 & 4.00 \\
\hline Bitkisel yağ & 2.25 & 2.25 & 2.25 & 2.25 \\
\hline Kireç taşı & 8.05 & 8.05 & 8.05 & 8.05 \\
\hline Dikalsiyum fosfat & 2.00 & 2.00 & 2.00 & 2.00 \\
\hline Tuz & 0.35 & 0.35 & 0.35 & 0.35 \\
\hline DL-Metiyonin & 0.10 & 0.10 & 0.10 & 0.10 \\
\hline Vitamin premiksi $^{1}$ & 0.25 & 0.25 & 0.25 & 0.25 \\
\hline Mineral premiksi ${ }^{2}$ & 0.10 & 0.10 & 0.10 & 0.10 \\
\hline Askorbik asit & - & 0.15 & 0.30 & 0.45 \\
\hline Toplam & 100.00 & 100.00 & 100.00 & 100.00 \\
\hline \multicolumn{5}{|l|}{ Analitik değerler } \\
\hline Ham protein, \% & 17.08 & 17.16 & 16.85 & 17.11 \\
\hline $\mathrm{ME}, \mathrm{kcal} / \mathrm{kg}^{3}$ & 2715 & 2713 & 2710 & 2708 \\
\hline Ham selüloz, \% & 3.43 & 3.12 & 3.19 & 3.51 \\
\hline Ham yağ, \% & 4.86 & 5.10 & 4.55 & 4.73 \\
\hline Ham kül, \% & 13.37 & 14.13 & 14.37 & 13.79 \\
\hline $\mathrm{Ca}, \%^{3}$ & 3.60 & 3.60 & 3.60 & 3.60 \\
\hline Toplam P, $\%^{3}$ & 0.86 & 0.86 & 0.86 & 0.86 \\
\hline Metiyonin, $\%^{3}$ & 0.41 & 0.41 & 0.41 & 0.41 \\
\hline Met. +sist., $\%^{3}$ & 0.67 & 0.67 & 0.67 & 0.67 \\
\hline Lisin, $\%^{3}$ & 0.80 & 0.80 & 0.80 & 0.80 \\
\hline
\end{tabular}

1) Vitamin premiksi rovimiks 124: Her 2.5 kg'da 12.000 .000 IU vitarnin A, 1.500 .000 IU Vitamin D3, $20.000 \mathrm{mg}$ vitamin $\mathrm{E}, 5.000 \mathrm{mg}$ vitamin $\mathrm{K} 3,3.000 \mathrm{mg}$ vitamin $\mathrm{B} 1,6.000$ $\mathrm{mg}$ vitamin $\mathrm{B2}, 25.000 \mathrm{mg}$ niasin, $12.000 \mathrm{mg}$ Ca-D-pantclenat, $5.000 \mathrm{mg}$ vitamin $B 6$ $30 \mathrm{mg}$ vitamin $112,1.000 \mathrm{mg}$ folik asit, $50 \mathrm{mg}$ D-biotin, $400.000 \mathrm{mg}$ kolin kloric $25.000 \mathrm{mg}$ karofil sarı içermektedir.

2) Mineral premiksi remineral 1: Her kg'da $80.000 \mathrm{mg}$ mangan, $30.000 \mathrm{mg}$ demir $60.000 \mathrm{mg}$ çinko, $5.000 \mathrm{mg}$ bakir, $500 \mathrm{mg}$ kobalt, $2.000 \mathrm{mg}$ iyot, $235.680 \mathrm{mg}$ kalsiyum içermektedir.

3) Hesaplanan değerleri göstermekłedir.

Çizelge 2. Deneme kümesinin ortalama sıcaklıkları $\left({ }^{\circ} \mathrm{C}\right)$

\begin{tabular}{|c|c|c|c|}
\hline Hafta & Ortalama & Minimum $^{*}$ & Maksimum $^{*}$ \\
\hline 1 & $23.14 \pm 0.46$ & $21(3)$ & $26(2)$ \\
\hline 2 & $24.42 \pm 0.73$ & $20(2)$ & $28(1)$ \\
\hline 3 & $24.07 \pm 0.55$ & $21(1)$ & $27(1)$ \\
\hline 4 & $24.07 \pm 0.71$ & $23(2)$ & $31(1)$ \\
\hline 5 & $25.42 \pm 0.66$ & $22(1)$ & $29(1)$ \\
\hline 6 & $26.00 \pm 0.70$ & $21(1)$ & $30(1)$ \\
\hline 7 & $25.35 \pm 0.66$ & $22(1)$ & $29(2)$ \\
\hline 8 & $24.85 \pm 0.74$ & $21(2)$ & $28(3)$ \\
\hline 9 & $23.71 \pm 0.74$ & $20(2)$ & $27(2)$ \\
\hline 10 & $24.85 \pm 0.81$ & $20(1)$ & $29(2)$ \\
\hline 11 & $21.78 \pm 0.70$ & $18(1)$ & $26(1)$ \\
\hline 12 & $20.00 \pm 0.48$ & $17(2)$ & $23(1)$ \\
\hline
\end{tabular}

* Parantez içindeki rakamlar gün sayısını göstermektedir.

Deneme sonunda ortalama canlı ağıriı̆ı temsilen her gruptan alınan 3 tavukta, yapılacak analize uygun şekilde damardan kan alınarak analize hazırlanmışdır (Çalışkaner 1985). Kan numunelerinin aninda serumu ayrilarak, alınan örneklerde askorbik asit değerleri spektrofotometrik yöntemle (Omaye ve ark. 1979); kalsiyum değerleri ise dijital Technicon RA-XT Autoanalyser'da saptanmıştır.
Denemede yumurta verimi, yem tüketimi, yem değerlendirme sayısı, deneme başı ve deneme soriu canlı ağırlıkları, yumurta ağırlığı, kabuk ağırlığı, kabuk oranı, kabuk mukavemeti, kabuk kalınlıkları, yumurta akı genişliği, uzunluk ve yüksekliği, yumurta sarısının yükseklik ve genişlik değerlerine ait gruplar arasındaki farkiılıklar Tesadüf Parselleri Deneme Tertibinde Varyans Analizi Metodu, kırık-çatlak yumurta ile ölüm oranları Khikare $\left(\chi^{2}\right)$ testine (Düzgüneş ve ark. 1983) göre tesbit edilmiştir. Gruplar arasındaki farklılıkların önem derecelerinin belirlenmesinde Duncan testi (Düzgüneş ve ark. 1987) uygulanmıştır.

\section{Bulgular ve Tartışma}

\section{Yumurta verimi}

Deneme gruplarına ait yumurta verimleri adet ve \% (tavuk/gün) olarak Çizelge 3'te verilmiştir. Diğer haftalarda görülmemesine rağmen denemenin 4. haftasında 2. grup, 1. ve 4 . gruptan $(P<0.01) ; 5$. haftasında ise 3 . grup, 1. 4. gruptan $(P<0.05)$ önemli derecede yüksek yumurta verimi sağlamışlardır.

\section{Yem tüketimi}

Denem gruplarının yem tüketimleri (g./tavuk/gün) Çizelge 4'de verilmiştir. Denemenin yalnızca 2 . haftasında 1. ve 4. grup özellikle 3 . gruptan $(P<0.01) ; 12$. haftasında ise kontrol grubu diğerlerinden $(P<0.05)$ daha az yem tüketmişlerdir.

\section{Yem değerlendirme}

Deneme gruplarına ait beher düzine yumurta verimi için tüketilen yem miktariarı (g. yem / düzine yumurta) Çizelge 5'de verilmiştir. Denemenin diğer haftalarında görülmemesine rağmen 2 . haftasında 2 . ve 3 . grup diğerlerinden daha yüksek $(P<0.05) ; 8$. haftasında 3 . grup özellikle 1. ve 4 . gruptan daha düşük $(P<0.05)$ yem değerlendirme sayısı göstermiştir.

\section{Bazı performans, yumurta ve kan parametreleri}

Deneme gruplarının bazı performans, yumurta ve kan parametrelerine ait sonuçlar Çizelge $6^{\prime} \mathrm{da}$ verilmiştir. Üzerinde durulan kriterlerden sadece yumurta akı genişliği gruplara göre farklı bulunmuştur $(P<0.05)$. Bu kriter açısından 1. ve 2. grup özellikle 4. gruptan daha yüksek değer vermiştir. Deneme süresince sırasıyla 1, 1,--, 1 tavuk öImüştür. Yapılan $\chi^{2}\left(\chi^{2}=1.0\right)$ testiride gruplara ait ölümlerin rasyondan bağımsız olduğu saptanmıştır $(P>0.05)$. Denemede ayrica gruplara ait sirasıyla 26,21 , 24, 19 adet kırık ve çatlak yumurta tesbit edilmiş ve yapılan $\chi^{2}\left(\chi^{2}=1.28\right)$ testinde kırık-çatlak oranlarının da rasyondan bağımsız olduğu saptanmıştır $(P>0.05)$.

Deneme grupları arasında 0-12 haftalık döneme ait bazı kriterler incelenecek olursa; yem değerlendirme sayısı, deneme başı ve sonu canlı ağırlık, yumurta ağırlığı, 
Çizelge 3. Deneme gruplarının ortalama yumurta verimleri, (\% tavuk/gün)

\begin{tabular}{|c|c|c|c|c|c|}
\hline \multicolumn{6}{|c|}{ Deneme grupları } \\
\hline Hafia & 1 & II & III & IV & $F$ \\
\hline 1 & $\begin{array}{c}5.65 \pm 0.17 \\
80.71 \pm 2.44\end{array}$ & $\begin{array}{c}5.55 \pm 0.17 \\
79.29 \pm 2.44\end{array}$ & $\begin{array}{c}5.35 \pm 0.05 \\
76.42 \pm 0.71\end{array}$ & $\begin{array}{c}5.75 \pm 0.26 \\
82.14 \pm 3.76\end{array}$ & $\begin{array}{l}0.90 \\
0.90\end{array}$ \\
\hline 2 & $\begin{array}{c}5.85 \pm 0.17 \\
83.57 \pm 2.44\end{array}$ & $\begin{array}{c}5.50 \pm 0.23 \\
78.57 \pm 3.40\end{array}$ & $\begin{array}{l}5.50 \pm 0.26 \\
78.57 \pm 3.78\end{array}$ & $\begin{array}{c}5.65 \pm 0.18 \\
80.71 \pm 2.70\end{array}$ & $\begin{array}{l}0.57 \\
0.57\end{array}$ \\
\hline 3 & $\begin{array}{c}4.60 \pm 0.14 \\
65.71 \pm 2.02\end{array}$ & $\begin{array}{c}4.75 \pm 0.12 \\
67.86 \pm 1.80\end{array}$ & $\begin{array}{c}4.80 \pm 0.29 \\
68.57 \pm 4.21\end{array}$ & $\begin{array}{c}4.60 \pm 0.14 \\
65.71 \pm 2.02\end{array}$ & $\begin{array}{l}0.30 \\
0.30\end{array}$ \\
\hline 4 & $\begin{array}{l}4.95 \pm 0.05 b^{x x} \\
70.71 \pm 0.71\end{array}$ & $\begin{array}{c}5.40 \pm 0.14 a^{x x} \\
77.14 \pm 2.02\end{array}$ & $\begin{array}{c}5.15 \pm 0.05 \mathrm{ab}^{\mathrm{xx}} \\
73.57 \pm 0.71\end{array}$ & $\begin{array}{c}4.90 \pm 0.05 b^{x x} \\
70.00 \pm 0.82\end{array}$ & $\begin{array}{l}7.29^{x} \\
7.29\end{array}$ \\
\hline 5 & $\begin{array}{l}5.00 \pm 0.08 b^{x} \\
71.43 \pm 1.17\end{array}$ & $\begin{array}{c}5.25 \pm 0.15 \mathrm{ab}^{x} \\
75.00 \pm 2.14\end{array}$ & $\begin{array}{c}5.60 \pm 0.08 \mathrm{a}^{x} \\
80.00 \pm 1.17\end{array}$ & $\begin{array}{l}4.90 \pm 0.25 b^{x} \\
70.00 \pm 3.60\end{array}$ & $\begin{array}{l}3.92^{\times} \\
3.92 \\
\end{array}$ \\
\hline 6 & $\begin{array}{c}5.65 \pm 0.18 \\
80.71 \pm 2.70\end{array}$ & $\begin{array}{c}5.80 \pm 0.14 \\
82.86 \pm 2.02\end{array}$ & $\begin{array}{c}6.00 \pm 0.24 \\
85.71 \pm 3.50\end{array}$ & $\begin{array}{c}5.35 \pm 0.17 \\
76.43 \pm 2.44\end{array}$ & $\begin{array}{l}2.07 \\
2.07 \\
\end{array}$ \\
\hline 7 & $\begin{array}{l}5.80 \pm 0.29 \\
82.86 \pm 4.21\end{array}$ & $\begin{array}{c}6.40 \pm 0.08 \\
91.43 \pm 1.17\end{array}$ & $\begin{array}{c}6.20 \pm 0.14 \\
88.57 \pm 2.02\end{array}$ & $\begin{array}{c}6.20 \pm 0.24 \\
88.57 \pm 3.50\end{array}$ & $\begin{array}{l}1.46 \\
1.46\end{array}$ \\
\hline 8 & $\begin{array}{c}6.00 \pm 0.16 \\
85.71 \pm 2.33\end{array}$ & $\begin{array}{c}6.25 \pm 0.15 \\
89.29 \pm 2.14\end{array}$ & $\begin{array}{c}6.45 \pm 0.09 \\
92.14 \pm 1.37\end{array}$ & $\begin{array}{c}5.95 \pm 0.22 \\
85.00 \pm 3.17\end{array}$ & $\begin{array}{l}2.01 \\
2.01\end{array}$ \\
\hline 9 & $\begin{array}{c}6.05 \pm 0.12 \\
86.43 \pm 1.80\end{array}$ & $\begin{array}{c}6.25 \pm 0.17 \\
89.29 \pm 2.447\end{array}$ & $\begin{array}{c}6.30 \pm 0.17 \\
90.00 \pm 2.47\end{array}$ & $\begin{array}{c}6.35 \pm 0.17 \\
96.71 \pm 2.44\end{array}$ & $\begin{array}{l}0.66 \\
0.66\end{array}$ \\
\hline 10 & $\begin{array}{c}6.00 \pm 0.11 \\
85.71 \pm 1.65\end{array}$ & $\begin{array}{c}6.25 \pm 0.12 \\
89.29 \pm 1.80\end{array}$ & $\begin{array}{c}6.20 \pm 0.08 \\
88.57 \pm 1.17\end{array}$ & $\begin{array}{c}6.30 \pm 0.17 \\
90.00 \pm 2.47\end{array}$ & $\begin{array}{l}1.05 \\
1.05\end{array}$ \\
\hline 11 & $\begin{array}{c}6.20 \pm 0.14 \\
88.57 \pm 2.02\end{array}$ & $\begin{array}{c}6.35 \pm 0.05 \\
90.71 \pm 0.71\end{array}$ & $\begin{array}{c}6.40 \pm 0.27 \\
91.43 \pm 3.87\end{array}$ & $\begin{array}{c}6.60 \pm 0.14 \\
24.29 \pm 2.02\end{array}$ & $\begin{array}{l}0.94 \\
0.94\end{array}$ \\
\hline 12 & $\begin{array}{c}5.95 \pm 0.18 \\
85.00 \pm 2.70\end{array}$ & $\begin{array}{c}6.15 \pm 0.05 \\
87.85 \pm 0.71\end{array}$ & $\begin{array}{c}6.40 \pm 0.14 \\
91.43 \pm 2.02\end{array}$ & $\begin{array}{c}6.30 \pm 0.10 \\
90.00 \pm 1.43\end{array}$ & $\begin{array}{l}2.24 \\
2.24 \\
\end{array}$ \\
\hline $0-12$ & $\begin{array}{l}67.70 \pm 0.78 \\
80.59 \pm 0.93\end{array}$ & $\begin{array}{l}69.90 \pm 0.88 \\
83.21 \pm 1.05\end{array}$ & $\begin{array}{l}70.35 \pm 0.60 \\
83.75 \pm 0.72\end{array}$ & $\begin{array}{l}68.85 \pm 0.61 \\
81.96 \pm 0.73\end{array}$ & $\begin{array}{l}2.61 \\
2.61\end{array}$ \\
\hline
\end{tabular}

a,b: Değişik harfileri taşıyan orialama değerler arasındaki farklılik istatistik olarak önernlidir $(x P<0.05 ; x x P<0.01)$

kabuk ağırlığı, kabuk oranı, kabuk küt kalınlığı ile ortalama kabuk kalınlığı, yumurta akı uzunluk ve yüksekliği, yumurta sarısı yükseklik ve genişliği, sarı indeksi, kırıkçatlak oranı, ölüm oranı, serum askorbik asit ve kalsiyum değerleri istatistik önemli farklılıklar vermemiştir $(P>0.05)$, Bu verilere dayanarak \% 0.45 'e kadar askorbik asit ilavesinin bu kriterleri etkilemediği sonucuna varılabilir. Bu bulgular rasyona ilave edilen askorbik asitin Herrick ve Nockels (1969), Erdinç (1977), Benabdeljelil ve ark. (1990)'nın kabuk ağırlığıni, Herrick ve Nockels (1969), Keckick ve Sykes (1974)'nın yumurta ağırlığı ve içinin kalitesini, Perek ve Kendler (1962), Nir (1990), Njoku ve ark. (1990)'nın kırık-çatlak yumurta oranını, Perek ve Kendier (1962), Cheng ve ark. (1990)'nın ölüm oranını, Benabdeljelil ve ark (1990)'nın canlı ağırlık artışını, Andrews ve ark. (1987)'nın yem değerlendirme sayısını, Rowland ve ark. (1973)'nın plazma kaisiyum seviyesini etkilemediğine ait bildirişleriyle uyum içindedir. Ancak, Conrad (1939) yüksek çevre sıcaklığının kanın kalsiyum taşıma kapasitesi üzerinde olumsuz etkide bulunduğunu bildirmektedir ki, denemede askorbik asit ilavesiyle serum kalsiyum arasında herhangi bir bağlantı saptanamamıştır. Herrick ve Nockels (1969), Perek ve Kendler (1962) sicak yaz aylarında yumurta tavuklarında rasyona askorbik asit ilavesinin plazma askorbik asit seviyesini yükselttiğini bildirmektedirler ki, bu denemede böyle bir bulgu elde edilememiştir. Muhtemelen tavukların aşırı sıcaklığa fazla maruz kalmamasından kaynaklanabilir. Kontrol grubunun, askorbik asit ilaveli gruplar seviyesine yakın çıkması, büyük olasilikla kesim esnasinda yaşanan stres nedeniyle bir miktar rezerv askorbik asidin kana verilmiş olmasından kaynaklanabilir. Nitekim Sauberlich (1994) stres esnasında kortikosteroidlerin yıkıcı etkisinden organizmanın korunması için özellikle adrenal korteksten kan dolaşımına önemli miktarda askorbik asit verildiğini bildirmektedir.

Denemede yumurta akı genişliğine ait değerler askorbik asit ilave seviyesine paralel olarak azalma eğiliminde olmuş, 4. grup özellikle 1. ve 2. gruptan düşük bulunmuştur. Bu durum, ilave edilen askorbik asitin bu kriter üzerinde düşürücü bir etkiye sahip olduğunu göstermektedir. Bu bulgular Perek ve Kendler (1962), Benabdeljelil ve ark. (1990), Njoku ve ark. (1990), Cheng ve ark. (1990)'nın yumurta ağırığını ve içinin kalitesini olumlu yönde etkilediğine ait bulgularıyla uyum içinde değildir. $0-12$ haftalık yumurta verimi ve yem tüketimi ile kabuk mukavemeti ve yumurtanın sivri uçtaki kalınlığına ait $F$ değerleri kritik sinıra yaklaşmış, bu parametreler kontrol grubunda diğerlerinden sayısal olarak daha düşük bulunmuştur. Bu verilere dayanarak askorbik asidin bu kriterleri sayısal olarak olumlu yönde etkilediği sonucuna varilabilir. Bu bulgular askorbik asidin Hunt ve Aitken (1962), 
Çizelge 4. Deneme gruplarının ortalama yem tüketimleri, (g/tavuk/gün)

\begin{tabular}{|c|c|c|c|c|c|}
\hline \multicolumn{6}{|c|}{ Deneme gruplan } \\
\hline Hafta & 1 & II & III & IV & $F$ \\
\hline 1 & $95.73 \pm 4.68$ & $101.96 \pm 1.94$ & $103.10 \pm 1.64$ & $96.64 \pm 1.58$ & 1.79 \\
\hline 2 & $99.94 \pm 3.60 b c^{20}$ & $107.28 \pm 2.47 \mathrm{ab}^{30 \mathrm{x}}$ & $110.46 \pm 0.72 a^{x x}$ & $97.35 \pm 1.96 c^{x \times}$ & $6.42^{x}$ \\
\hline 3 & $101.05 \pm 1.60$ & $107.39 \pm 4.00$ & $101.78 \pm 2.32$ & $98.21+2.69$ & 1.89 \\
\hline 4 & $81.33 \pm 1.37$ & $85.36 \pm 2.49$ & $88.63 \pm 4.74$ & $83.28 \pm 2.10$ & 1.11 \\
\hline 5 & $99.70 \pm 2.28$ & $107.39 \pm 1.94$ & $102.89 \pm 2.52$ & $103.24 \pm 2.81$ & 1.71 \\
\hline 6 & $106.75 \pm 1.96$ & $103.94 \pm 1.94$ & $108.32 \pm 2.92$ & $107.07+3.00$ & 0.54 \\
\hline 7 & $103.17 \pm 1.92$ & $106.57 \pm 1.51$ & $108.21 \pm 3.00$ & $102.53 \pm 2.57$ & 1.37 \\
\hline 8 & $103.49 \pm 1.65$ & $107.39 \pm 2.60$ & $105.39 \pm 0.39$ & $110.18 \pm 2.56$ & 1.15 \\
\hline 9 & $101.83 \pm 2.22$ & $104.18 \pm 1.18$ & $105.11 \pm 5.50$ & $100.96 \pm 3.06$ & 0.33 \\
\hline 10 & $107.15 \pm 2.45$ & $108.78 \pm 1.91$ & $109.32 \pm 4.67$ & $109.64 \pm 4.08$ & 0.10 \\
\hline 11 & $111.99 \pm 3.25$ & $113.64 \pm 1.59$ & $109.28 \pm 3.82$ & $115.03 \pm 1.90$ & 0.78 \\
\hline 12 & $110.03 \pm 1.66 b^{x}$ & $114.99 \pm 0.60 a^{x}$ & $114.42 \pm 2.86 a^{x}$ & $118.64 \pm 1.18 a^{x}$ & $3.93^{x}$ \\
\hline $0-12$ & $1228.1 \pm 9.9$ & $1268.9 \pm 8.6$ & $1266.9 \pm 15.1$ & $1242.8 \pm 11.9$ & 2.85 \\
\hline
\end{tabular}

a,b: Değişik harfleri taşıyan ortalama değerler arasındaki farklılı istatistik olarak önemlidir $(x P<0.05 ; x x P<0.01)$

Çizelge 5. Deneme gruplarının ortalama yem değerlendirmeleri, (g yem/düzine yumurta)

\begin{tabular}{|c|c|c|c|c|c|}
\hline \multicolumn{6}{|c|}{ Deneme gruplari } \\
\hline Hafta & 1 & II & III & IV & $F$ \\
\hline 1 & $1430.0 \pm 102.0$ & $1545.6 \pm 33.4$ & $1619.3 \pm 31.9$ & $1421.2 \pm 71.8$ & 2.06 \\
\hline 2 & $1434.4 \pm 15.3 b^{x}$ & $1643.5 \pm 43.0 a^{x}$ & $1700.2 \pm 92.1 a^{x}$ & $1453.1 \pm 64.0 b^{x}$ & 4.90 \\
\hline 3 & $1848.2 \pm 36.1$ & $1908.0 \pm 122.0$ & $1799.0 \pm 107.0$ & $1795.2 \pm 36.0$ & 0.39 \\
\hline 4 & $1381.2 \pm 35.1$ & $1330.5 \pm 51.9$ & $1446.7 \pm 82.7$ & $1429.1 \pm 49.3$ & 0.83 \\
\hline 5 & $1675.7 \pm 38.9$ & $1725.0 \pm 79.1$ & $1544.1 \pm 42.1$ & $1784.0 \pm 106.0$ & 2.01 \\
\hline 6 & $1594.0 \pm 72.8$ & $1508.5 \pm 26.2$ & $1524.7 \pm 80.1$ & $1690.5 \pm 99.0$ & 1.25 \\
\hline 7 & $1506.9 \pm 89.7$ & $1398.8 \pm 11.7$ & $1468.5 \pm 54.8$ & $1395.4 \pm 64.9$ & 0.78 \\
\hline 8 & $1536.4 \pm 57.4 a^{x}$ & $1446.1 \pm 52.0 a^{x}$ & $1373.2 \pm 17.2 b^{x}$ & $1558.6 \pm 35.1 a^{x}$ & $3.88^{x}$ \\
\hline 9 & $1415.8 \pm 42.7$ & $1403.3 \pm 42.0$ & $1410.0 \pm 111.0$ & $1336.0 \pm 26.1$ & 0.33 \\
\hline 10 & $1501.6 \pm 41.6$ & $1464.4 \pm 46.2$ & $1480.1 \pm 52.8$ & $1461.4 \pm 30.1$ & 0.18 \\
\hline 11 & $1522.5 \pm 76.2$ & $1503.9 \pm 31.2$ & $1436.4 \pm 26.3$ & $1465.0 \pm 22.5$ & 0.75 \\
\hline 12 & $1558.9 \pm 62.0$ & $1570.9 \pm 12.2$ & $1502.6 \pm 32.0$ & $1582.7 \pm 22.3$ & 0.91 \\
\hline $0-12$ & $1524.7 \pm 27.0$ & $1525.4 \pm 17.5$ & $1512.7 \pm 12.6$ & $1516.8 \pm 23.6$ & 0.09 \\
\hline
\end{tabular}

a,b: Değişik harfleri taşıyan ortalama değerler arasındaki farkilık istatistik olarak önemlidir $(x P<0.05)$

Sullivan ve Kingan (1962), Perek ve Kendler (1962), Kolb (1990), Nir (1990), Haazele ve ark. (1991)'nın yumurta verimini, Perek ve Kendler (1962), Benabdeljelil ve ark. (1990), Njoku ve ark. (1990), Cheng ve ark. (1990)'nın yumurta ağırlığı ve içinin kalitesini olumlu yönde etkilediğine ait bulgularıyla uyum içindedir. Buna karşın Thornton ve Moreng (1958), Benabdeljelil ve ark. (1990), Njoku ve ark. (1990)'nın yumurta verimini, Erdinç (1978)'in yem tüketimini etkilemediğine ait bildirişleri ile aynı doğrultuda değildir. Denemede istatistiki olarak önemli olmasada, askorbik asitli gruplarda kabuk mukavemeti ile ortalama kabuk kalınlığı sayısal olarak daha yüksek bulunmuş, bu durum kirık-çatlak oranına da yansımıştır. Deneme gruplarına ait yumurta akı indeksine ve yumurtanın orta kısmındaki kabuk kalınlığına ait $F$ değerleri yine kritik sınıra yaklaşınış, ancak bu kriterler askorbik asitli gruplar lehine yada aleyhine bir azalma yada bir yükselme göstermemiştir. 
Çizelge 6. Deneme gruplarının ortalama bazı performans, yumurta ve kan parametreleri

\begin{tabular}{|c|c|c|c|c|c|}
\hline \multirow{2}{*}{ Kriterler } & \multicolumn{3}{|c|}{ Deneme gruplan } & \multirow[b]{2}{*}{ IV } & \multirow[b]{2}{*}{$F$} \\
\hline & 1 & II & III & & \\
\hline Deneme başı CA, $g$ & $1345.0 \pm 26.6$ & $1347.5 \pm 21.9$ & $1325.0 \pm 20.4$ & $1357.5 \pm 21.5$ & 0.36 \\
\hline Deneme sonu CA,g & $1632.6 \pm 42.7$ & $1608.3 \pm 23.0$ & $1644.5 \pm 35.8$ & $1664.3 \pm 28.3$ & 0.51 \\
\hline Canlı ağırlık artışı, g & $293.2 \pm 45.5$ & $260.7 \pm 26.8$ & $319.5 \pm 34.9$ & $306.7 \pm 28.3$ & 0.55 \\
\hline Ölüm miktarı, adet & 1 & 1 & - & 1 & \\
\hline Ölüm oranı, \% & 5.00 & 5.00 & 0.00 & 5.00 & \\
\hline Yumurta ağırlığı, g & $59.14 \pm 0.62$ & $58.62 \pm 0.63$ & $59.24 \pm 0.59$ & $58.44 \pm 0.66$ & 0.38 \\
\hline Kabuk ağırlığı,g & $8.32 \pm 0.10$ & $8.44 \pm 0.17$ & $8.32 \pm 0.11$ & $8.27 \pm 0.14$ & 0.26 \\
\hline Kabuk oranı, $\%$ & $14.11 \pm 0.20$ & $14.40 \pm 0.24$ & $14.07 \pm 0.18$ & $14.16 \pm 0.18$ & 0.51 \\
\hline Kabuk mukavemeti, $\mathrm{kg} / \mathrm{cm}^{2}$ & $3.07 \pm 0.13$ & $3.23 \pm 0.14$ & $3.27 \pm 0.15$ & $3.57 \pm 0.13$ & 2.13 \\
\hline Kırik-çatlak miktarı, adet & 26 & 21 & 24 & 19 & \\
\hline Kurık-çatlak oranı, $\%$ & 7.60 & 6.00 & 6.82 & 5.51 & \\
\hline Kabuk küt kalınlığı, $\mu$ & $367.7 \pm .6 .8$ & $383.3 \pm .5 .0$ & $368.6 \pm 5.2$ & $380.8 \pm 5.3$ & 0.78 \\
\hline Kabuk orta kalınlığı, $\mu$ & $384.1 \pm 4.4$ & $378.6 \pm 4.1$ & $388.6 \pm 5.0$ & $367.7 \pm 6.8$ & 2.05 \\
\hline Kabuk sivri kalınlığı, $\mu$ & $381.6 \pm 5.7$ & $390.8 \pm 5.2$ & $393.0 \pm 5.9$ & $403.6 \pm 5.8$ & 2.50 \\
\hline Ortalama kabuk kailınlığı, $\mu$ & $377.8 \pm 31.6$ & $386.1 \pm 2.47$ & $380.0 \pm 27.2$ & $391.0 \pm 28.9$ & 1.60 \\
\hline Ak yüksekliği, mm & $6.82 \pm 0.26$ & $6.22 \pm 0.26$ & $6.78 \pm 0.21$ & $6.90 \pm 0.24$ & 1.54 \\
\hline Sarı yüksekliği, mm & $15.25 \pm 0.12$ & $15.07 \pm 0.18$ & $15.07 \pm 0.11$ & $15.33 \pm 0.08$ & 1.04 \\
\hline Ak genişliği, cm & $5.41 \pm 0.11 \mathrm{a}^{\mathrm{x}}$ & $5.32 \pm 0.10 a^{x}$ & $5.27 \pm 0.09 a b^{x}$ & $4.97 \pm 0.12 b^{x}$ & $2.85^{x}$ \\
\hline Ak uzunluğu, $\mathrm{cm}$ & $7.44 \pm 0.15$ & $7.58 \pm 0.10$ & $7.42 \pm 0.09$ & $7.16 \pm 0.13$ & 1.94 \\
\hline Sarı genişliği, cm & $2.60 \pm 0.03$ & $2.57 \pm 0.02$ & $2.57 \pm 0.03$ & $2.57 \pm 0.03$ & 0.20 \\
\hline Ak indeksi, \% & $10.81 \pm 0.53$ & $9.71 \pm 0.43$ & $10.81 \pm 0.44$ & $11.65 \pm 0.60$ & 2.44 \\
\hline Sarn indeksi, \% & $58.88 \pm 0.83$ & $58.76 \pm 0.93$ & $58.78 \pm 0.84$ & $59.99 \pm 0.88$ & 0.46 \\
\hline Serum askorbik asit,mg/100 mi & $18.46 \pm 2.83$ & $19.74 \pm 1.80$ & $22.20 \pm 1.70$ & $22.96 \pm 1.91$ & 0.99 \\
\hline Serum $\mathrm{Ca}_{1} \mathrm{mg} / 100 \mathrm{ml}$ & $14.00 \pm 1.58$ & $17.75 \pm 1.07$ & $14.63 \pm 0.63$ & $15.98 \pm 1.37$ & 1.86 \\
\hline
\end{tabular}

a,b: Değişik harfleri taşıyan ortalama değerler arasındaki farklılık istatistik olarak önemlidir $(x P<0.05)$

\section{Sonuç}

17-31 ${ }^{\circ} \mathrm{C}$ sıcaklığa sahip yaz aylarında yumurta tavuğu rasyonlarına \% 0.45 'e kadar ilave edilen askorbik asitin, yem değerlendirme sayısı, yumurta ağırlığı, kabuk ağırlığı, kabuk oranı, küt kısımdaki kabuk kalınlığı ile ortalama kabuk kalınlığı, yumurta akı uzunluk ve yüksekliği, yumurta sarısı yükseklik ve genişliği, sarı indeksi, kırık-çatlak oranı, ölüm oranı, serum askorbik asit ve kalsiyum değerlerini etkilemediği, ancak yumurta verimi, yem tüketimi, ortalama kabuk mukavemeti, ortalama yumurtanın sivri uçtaki kabuk kalınlığını sayısal olarak olumlu yönde $(P>0.05)$, yumurta akı genişliğini ise olumsuz yönde önemli derecede etkilediği söylenebilir $(P<0.05)$.

\section{Kaynaklar}

Akyıldız, A. R., 1979. Karma Yemler Endüstrisi. San Matbaası. Ankara. Vill+218s

Akylldiz, A. R., 1984. Yemler Bilgisi Laboratuvar Kılavuzu. A.U. Zir. Fak. Yay 895. Uygulama Kılavuzu. 213. III+236s.

Andrews, D. K. , W.D. Berry and J. Brake, 1987 Effect of lighting program and nutrition on reproductive performance of molted single comb white leghorn hens. Poult. Sci. 66. 8: 1298-1305.
Anonymous, 1984. Nutrient Requirements of Poultry. National Research Council. Eighth Revised Edition. National Academy Press. 2101. Constitution Ave., N. W. , Washington DC. 20418.

Benabdeljelil, K. , A. Riyadi. and L.S. Jensen, 1990. Effect of dietary ascorbic acid supplementation on the performance of brown-egg layers and egg quality. Animal Feed Science and Technology. 30.4: 301-311.

Cheng, T. K. C.N. Coon and M.L. Hamre, 1990. Effect of environmental stress on the ascorbic acid requirement of laying hens. Poultry Science. 52: 1862-1867.

Conrad, R. M. , 1939. The effect of high temperature on the biood calcium of the laying hen. Poult. Sci. 18: 327-329.

Çalışkaner, S. , 1985. Hayvan Besleme Laboratuvar Teknikleri. A.Ü. Zir. Fak. Yay. 942. Ankara. $111+218$ s.

Düzgüneş, O. , T. Kesici ve F. Gürbüz, 1983. Istatistik Metotlari-I. A.U. Zir. Fak. Yay. 861 Ders Kitabı. 229. 1.228. Ankara.

Düzgüneş, O., T. Kesici, O. Kavuncu ve F.Gürbüz, 1987. Araștırma ve Deneme Metotları (Istatistik Metotları II). A.Ü. Zir. Fak. Yay. 1021. Ders Kitabı 295. Ankara. 
Erdinç, H. , 1977. Leghorn civciv ve tavuklarında askorbik asidin büyüme, yumurta verimi ve yumurta kabuğu kalitesine etkisi. Gıda-Tarım ve Hayvancılık Bakanlığı. Lalahan Zootekni Araştırma Enstitüsü Yayınları No:55. 37s.

Haazele, F., W. Guenter, R.R.Marquardt. and A. Frolich, 1991. Effect of ochratoxin A (OA) and/or ascorbic acid (AA) supplementation on production in laying hens. Poult. Sci. 70. Abstract 47.

Herrick, R. B. and C.F. Nockels, 1969. Effect of a high level of ascorbic acid on egg quality. Poult. Sci. 48: 1518-1519.

Hunt, J. R. and A.H. Aitken, 1962. Studies on the influence of ascorbic acid on shell quality. Poult. Sci. 41:219-226.

Kechik, L. T., and A.H. Sykes, 1974. Effect of dietary ascorbic acid on the performance of laying hens under warm environmental conditions. Bri. Poult. Sci. 15: 449-457.

Kolb, E. , 1990. The Use Ascorbic Acid in Animal Nutrition and Veterinary Medicine. Proceedings of the Second Symposium on Ascorbic Acid in Domestic Animals. Kartause. Ittingen. Switzerland: 96-113.

Kutlu, H. , 1996. Sicaklik stresine maruz kaian etlik piliçlerin performanslarının korunmasında beslemenin önemi. Yem Magazin. Ağustos Sayısı. 49-56.

Marsden, A., T.R. Morris and A.S. Coomanty, 1987. Effect of constant environmental temperature on the performance of laying pullets. Br. Poult. Sci. 28: 361-380.

Nir, I. , 1990. Influence of Supplemental Ascorbic Acid on Broiler, Layer and Waterfowl Performance. Proceedings of the Second Symposium on Ascorbic Acid in Domestic Animals. Kartause. Ittingen. Switzerland: 286-291.
Njoku, P. C., C.C. Whitehead and M.A. Mitchell, 1990. Heat Stress and Ascorbic Acid Effects on the Production Characteristics of Chickens Under Controlled and Uncontrolled Temperature Conditions. Proceedings of the Second Symposium on Ascorbic Acid in Domestic Animals. Kartause. Ittingen. Switzerland: 251-261.

Omaye, S. T., J.D. Turnbull and H.E. Sauberlich, 1979. Sellected Metods for the Determination of Ascorbic Acid in Animal Cells, Tissues and Fluids. Metods Enzymol. 62 : 1-7.

Orban, J. I., D.A. Roland, S.K. Cummins. and R.T. Lovell, 1993. Influence of large doses of ascorbic acid on performance, plasma calcium, bone characteristics and eggshell quality in broilers and leghorn hens. Poult. Sci. 72:691-700.

Perek, M. and J. Kendler, 1962. Research note: vitamin C supplementation to hens'diets in a hot climate. Poult. Sci.41.2:677-678.

Rowland, L. O., D.A. Roland and R.H. Harms, 1973. Ascorbic acid as related to tibia strength in spent hens. Poult. Sci. 52:347350.

Sauberlich, H. E., 1994. Pharmacology of Vitamin C. Annual Rev. Nutr. 14: 371-391.

Sullivan, T. W. and J.R. Kingan, 1962. Effect of dietary calcium level, calcium lactate and ascorbic acid on production of S.C. white leghorn hens, Poult. Sci.41:1596-1602.

Thornton, P. A. and R.E. Moreng, 1958. The effects of ascorbic acid on egg quality factors. Poult. Sci. $37: 691-698$. 